\title{
Songah in the Cultural Tourism Industry
}

\author{
Ridwan*, Tati Narawati, Uus Karwati, Yudi Sukmayadi \\ Pendidikan Seni Sekolah Pasca Sarjana \\ Universitas Pendidikan Indonesia \\ Bandung, Indonesia \\ *Ridwansimon@student.upi.edu
}

\begin{abstract}
Indonesia has 460 ethnicities which can be called a multicultural country. Cultural diversity is one of the things that can be developed in the field of tourism. Including art which is a part of culture can be used as a tourist attraction. One of them is the art of Songah in Citengah Village, Sumedang Regency. Efforts to develop arts into tourist attractions need to be carried out through cooperation between the community and the government, the promotion of tourist attractions, accessibility and facilities and infrastructure that support tourism activities. The purpose of this study is to describe the development of songah art in the cultural tourism industry as a tourist attraction. By using a qualitative approach and descriptive methods, it is revealed in depth about songah art in the tourism industry based on culture or local wisdom. The results of this study indicate that the development of songah art as a tourist attraction has an effect on the cultural tourism industry, and also affects the lives of the people who support the art. This is done by fulfilling the $4 \mathrm{~A}$ elements which include Attraction, Accessibility, Amenities, and Ancillary Service.
\end{abstract}

Keywords—cultural tourism industry, traditional arts, Songah

\section{INTRODUCTION}

Many management and development activities of traditional arts with local wisdom values are used as part of the tourism industry. Several related studies, among others, were conducted by Saarinen et al., with the research title "Cultural tourism: New opportunities for diversifying the tourism industry in Botswana". The research describes cultural tourism which is the main potential to be able to contribute to the tourism industry and the economy of Bostwana [1]. Cultural tourism studied in this study is related to restoration, preservation and conservation of cultural and natural heritage resources. Research conducted by Csapo entitled "The Role and Importance of Cultural Tourism in Modern Tourism Industry" describes the development of cultural tourism which is constantly being updated following the times [2]. This is done not only to meet the demands of the community but also to motivate tourists to visit.

Irianto conducted a research entitled "Traditional Arts as a Tool for Cultural Strategy in the Middle of Determination of Communication Technology". The research describes the use of technology in cultural tourism activities which aims to pass down traditional arts [3]. Research conducted by Priono entitled "The Study on the Impact of Bukit Batu Tourism in Kasongan Regency in terms of Economic, Social and Cultural Aspects" illustrates the impact of the involvement of arts in parisiwsata industrial activities [4]. This is done through the empowerment of Human Resources (HR) so that it has an impact on increasing community appreciation in artistic activities.

Indonesia is an archipelago country. Consists of various ethnic groups, each of which has customs, values or norms, cultural heritage, language, and arts. This diversity is an asset that becomes the identity of an area, especially for the nation and state. With regard to cultural preservation, the community and government need to make several efforts, namely by developing a culture-based tourism sector. In Law No. 10 of 2009 concerning tourism, it is explained that tourism is a variety of things related to tourism activities and is supported by various existing facilities such as services provided by: the community, businessmen, government or local governments. The existence of natural resources and works of art in each region can be used as a culture-based tourist destination [5].

Sunaryo argues that cultural tourism is a type of tourist attraction based on human works of art both in the form of cultural relics and cultural values that are still alive today [68]. One area that has unique and interesting tourism potential is Sumedang District, Indonesia, which was previously stipulated in the Sumedang Regional Regulation No.113 of 2009 as the center of Sundanese culture [9]. In this area, there are many tourism potentials such as: Margawindu tea plantation, Cigorobog waterfall water tourism, Saung Cibingbin, and Karuhun village with Eco Green Park. In addition, in the area, there are also various crafts and songah music that use bamboo plants as the basic material for their manufacture [10-11].

Of the various types of tourism potential that exist, one that can be favored is Songah art. Songah art is an art originating from Citengah Village, Sumedang Regency. Songah art has instruments made from bamboo which grows in the area. These bamboos are specially cut, made in various sizes to produce different timbre that are played by blowing them and can be flexibly combined with other musical instruments to become an orchestra. As an artistic innovation, songah art is presented in cultural festival activities at local, regional and national levels. In the field of cultural tourism industry, songah art can be developed into a tourist attraction. Based on existing 
phenomena, researchers reveal, explore and interpret and explain in depth about the development of songah art in the cultural tourism industry in Citengah Village, Sumedang Regency as a form of cultural preservation in the area.

The scope of the discussion of this writing is emphasized in the formulation of the problem "How is the development of songah art as part of the cultural tourism industry?".

\section{A. Songah Art}

Songah art consists of 6 kinds of musical instruments, namely as follows:

1) Songsong Buhun / Besar (goong): Songsong Buhun / Large with a size of $115 \mathrm{~cm}$ and a diameter of $5 \mathrm{~cm}$ which functions as a goong. It is played by blowing it and it is done by vibrating the lips so that it will produce a sound with a distinctive timbre of the songong buhun.

2) Songsong Kecil (drums): Songsong Kecil measuring 75 $\mathrm{cm}$ with a diameter of $3 \mathrm{~cm}$ which functioned as Ryhtem (drums). For the way to play the songong is the same as the way to play the songong buhun / big, that is by blowing it with the technique of vibrating the lips, it will produce a distinctive sound from the songong / drum.

3) Big hatong: A large hatong measuring $20 \mathrm{~cm}$ by $5 \mathrm{~cm}$ in diameter. The way to play it is to blow it and the hatong hole in the Tangkep (open-close) it will produce a sound color like the sound of a bird.

4) Little hatong: Small hatong measuring $10 \mathrm{~cm}$ with a diameter of $3 \mathrm{~cm}$. The way to play the small hatong is the same as the way to play the big hatong, namely by using the hatong hole that is opened and closed.

5) Kokoprak: The size of the kokoprak is not determined, it is made according to taste. Kokoprak functions as a rhythm to regulate the rhythm musical ensemble.

6) Flute: The basic material for making this songah musical instrument comes from awi tamiang which is bamboo which is often used in making art. This songah instrument can play diatonic and pentatonic tones and has high flexibility to be able to collaborate with music genres and other musical instruments.

\section{B. Cultural Tourism}

Tourism is closely related to art and culture. In tourism activities, it covers several aspects of life, including economic, social, cultural, and various other aspects of community life. Culture as an area's identity can be used as an attraction for tourists. According to Cooper tourists in traveling have motivation [12-15], namely; 1) Seeing something, getting a different experience from the environment where he lives, 2) Knowing the interesting things about a tourist destination, 3) Visiting with a specific purpose such as visiting friends, relatives, study interests and others, 4) Looking for something or experiences that are different from everyday life, and 5)
Based on stories or experiences that are different from everyday habits.

According to Huges with tourism, interactions can occur between communities and ultimately it can preserve or enhance artistic heritage $[16,17]$. From these interactions will arise a process of mutual influence which will have an impact on changes in the structure of life of the community or even the cultural patterns of society. The attraction of cultural tourism is culture that is tangible and culture that is intangible. Cultural tourism covers 4A aspects, namely: Attraction, Accessibility, Amenities, and Ancillary Service [18].

\section{RESEARCH Methods}

This research uses a descriptive qualitative approach in order to obtain more detailed, complete and in-depth data. This research was conducted through several stages, namely data collection, data analysis, and evaluation using observation, interview, and relevant literature review techniques [19]. The research location was in Citengah Village, Sumedang Regency, West Java.

\section{Results AND Discussion}

Songah is one of the most favored arts by the Sumedang community, especially around Citengah Village. Songah is a heritage art made of bamboo. At first, the art of songah was known as the palace musical instrument because the instrument was dedicated to the palace or the kingdom which was performed at sacred activities, welcoming great guests, and so on. With the development of the times, this art has almost been eliminated and lost its existence. However, the awareness of the surrounding community led by $\mathrm{Ki}$ Madhari as the traditional leader in the area made the songah music community in an effort to preserve the art of songah music. The songah music community tries to uncover and re-develop the art of songah by starting to show it at hajat overtime activities.

Tourism has an important role in the effort to preserve the arts. In an effort to develop the tourism industry, songah art is used as a tourist attraction and continues to experience renewal. In this regard, several things that need to be considered include the nature of social change in terms of modernization, industrialization and the economic development that followed. [20]

Songah art in the tourism industry has attractions, namely:

- Something To See. Songah art as a tangible tourist attraction. Because the art of songah is in the form of a show which can be seen and enjoyed by tourists. One of the efforts made by the people who support songah music is by implementing performance management from planning to evaluation. In line with this, supporters of an art in management are divided into two, namely supporters of artistic affairs which include people who have expertise in the arts, and non-artistic supporters which include people who work outside the art field 
[21]. Planning is the first and foremost step in managing an art activity. This also relates to targets that are adjusted to specific, measurable, attainable, realistic, and time oriented criteria [22].

- Something To Do. In this case, the songah music community provides an opportunity for tourists to try to play songah music. For tourists who visit, not only can they see the songah art performance, but tourists can try to play this musical instrument guided by existing artists and communities with a simplified process. Thus, this can be one of the things that can encourage tourists to continue to make repeat visits to Citengah Village.

- Something To Buy. In addition to the songah performance which is an attraction for tourists, the supporting elements such as the art of craftsmanship as a characteristic of the Citengah village area. The craft art is the work of local people who take advantage of natural resources such as the many bamboo plants that exist in the Citengah Village area.

In its development in the field of cultural tourism, songah art must pay attention to the characteristics as expressed [22] as follows:

- An imitation of the original. Songah art form as part of art tourism certainly has a difference from the original form. The existing new form does not mean leaving the distinctive features and cultural traditions that surround it. However, this songah art continues to experience development in the form of a new presentation and is packaged as an art tourist attraction that maintains existing cultural values.

- Short and concise. In an art attraction in tourism activities, songah art in its presentation needs to be packaged in a shortened duration to streamline time. Because at the time the songah art was a traditional art that was performed in sacred events, this art had a fairly long performance duration.

- Full of variety. Along with the development of the times, and in an effort to attract the attention of the public, especially tourists, the art of songah has undergone several changes and there are quite a lot of variations used compared to before. Currently songah performances are equipped with several western musical instruments such as piano, guitar, violin, keyboard, and others. In addition, songah art also displays works according to the times. Songah art which is full of variations makes songah art look more modern but still does not leave its original tradition.

- The sacred, magical and symbolic values should be removed. Although this songah art continues to experience development both in form and presentation, this art still contains sacred values because it is seen from the very beginning that songah art is a traditional art that is only displayed on ritual events.
- Cheap or affordable for tourists. This songah art must be packaged in an attractive manner and as a show that can be reached by everyone so that this art can be enjoyed not only by tourists, but also by the people who support it.

As part of the tourism industry, songah art also needs to cover $4 \mathrm{~A}$ aspects $[7,15]$.

- Attraction. Attraction is a core component in attracting tourists to come to a tourist spot. Things that are developed into tourist attractions are called tourism resources. Tourism capital according to Suwena $[7,23,24]$ is tourist attractions in tourist attractions (in situ) and outside their original places (ex situ). There are three main attractions to attract tourist arrivals, namely; 1) Natural Resources (natural), 2) Cultural Tourism Attractions, and 3) Man-made attractions themselves [15]. The existence of tourist attractions is very important to motivate tourists to visit tourist attractions in an area. Citengah Village has all the attractions that have been mentioned. Natural Resources, which include natural tourism, are available. Songah art in Citengah Village is classified as a cultural tourism attraction, where every tourist will be presented in an interesting show. The third is the man-made attraction itself which includes various kinds of craft art created by the people of Citengah village which are sold as souvenirs for tourists.

- Accessibility. Accessibility covers all the facilities that make it easy for tourists to reach a destination and related tourist destinations. Accessibility in the form of transportation services that can facilitate access for tourists to travel from one area to another. Factors related to accessibility include directions, airports, terminals, and the time it takes to get to the location. In this case, the community collaborates with the government in an effort to conserve existing facilities and infrastructure in the Citengah Village area.

- Amenities. Amenities according to Sugiana are a series of facilities to meet the needs of accommodation (lodging), food and beverages, entertainment venues, shopping places and others [7]. Apart from lodging used by tourists, restaurants or restaurants that provide specialties from the Citengah Village area are also the main attraction for tourists. Another aspect of aminities is the provision of a bureau such as tours and travel that can facilitate tourists in tourism activities in the village area.

- Ancillary service. Ancillary Service according to Sunaryo is the availability of public facilities and infrastructure needed by tourists who also support the implementation of tourism activities, for example ATM, hospitals, and others [7]. Ancillary Service is an additional service that must be provided by the local government to facilitate tourists. As in the area of 
Citengah Village, ATM machines are already available, although not too many.

Promotional activities are no less important in the cultural tourism industry. Songah promotion can be done in various ways. One of them is online media. Performers of the arts and the community support the art of songah music to promote by utilizing existing technology. Art actors and the supporting community make a video of songah music performance which is then shared on social media such as YouTube and so on so that everyone can watch and know songah art originating from Citengah Village and encourage tourists to come to visit the village. Because basically it is in line with what Sukmayadi expressed in their research that there are three main supporters in performing arts activities, namely suppliers, performing artists who work on innovative works, and stakeholders or buyers [25].

\section{CONCLUSIONS}

The potentials in Citengah Village, Sumedang Regency, need to be developed in an effort to preserve culture through the cultural tourism industry. One thing that can be used as a tourist attraction is songah art. In an effort to develop songah art in the cultural tourism industry, it is necessary to pay attention to the 4A aspects which include Attraction, Accessibility, Amenities, and Ancillary Service. In addition, promotional activities are also needed through pamphlets and using online media. From several things that have been described, efforts to develop songah art in the cultural tourism industry are not only carried out by the people who support the arts but it is also the responsibility of the government.

\section{ACKNOWLEDGMENTS}

The author would like to thank the parties involved in this research, either directly or indirectly. Especially to the Ministry of Education and Culture DIKTI who has facilitated research in the DOCTOR GRANT scheme, as well as the people of Citengah Village as the owner of the Songah art.

\section{REFERENCES}

[1] J. Saarinen, N. Moswete, and M.J. Monare, "Cultural tourism: New opportunities for diversifying the tourism industry in Botswana," Bull. Geogr., vol. 26, no. 26, pp. 7-18, 2014.

[2] J. Csapo, "The Role and Importance of Cultural Tourism in Modern Tourism Industry,” Strateg. Tour. Ind. - Micro Macro Perspect., 2012.

[3] A.M. Irianto, "Kesenian Tradisional Sebagai Sarana Strategi Kebudayaan di Tengah Determinasi Teknologi Komunikasi,” Nusa J. Ilmu Bhs. dan Sastra, vol. 12, no. 1, p. 90, 2017.

[4] Y. Priono, "Studi Dampak Pariwisata Bukit Batu Kabupaten Kasongan di Tinjau dari Aspek Ekonomi, Sosial, dan Budaya," J. Prespektif Arsit., vol. 6, no. 2, pp. 23-33, 2011.
[5] Presiden Republik Indonesia, "Undang-Undang Republik Indonesia Nomor 10.Tahun 2009," vol. 2, p. 3500, 2009

[6] F. Badarab, E. Trihayuningtyas, and M.L. Suryadana, "Strateg Pengembangan Destinasi Pariwisata di Kepulauan Togean Provins Sulawesi Tengah," J. Tour. Hosp. Essentials J., vol. 7, no. 2, p. 97, 2017.

[7] K. Khotimah, "Strategi Pengembangan Destinasi Pariwisata Budaya (Studi Kasus pada Kawasan Situs Trowulan sebagai Pariwisata Budaya Unggulan di Kabupaten Mojokerto )," Jurnal Administrasi Bisnis, vol. 42, no. 1, pp. 56-65, 2017

[8] I. Bagus and K. Wanda, "Kepuasan Pengunjung (Survei pada Pengunjung Situs Trowulan)," Jurnal Administrasi Bisnis (JAB), vol. 55, no. 3, pp. 83-91, 2018

[9] Bupati Sumedang, "Peraturan Bupati Sumedang No 113 Tahun 2009,' 2009.

[10] A.M. Imanuddin, "Desa Citengah, Sumedang Tandang BPS Kabupaten Sumedang," $2017 . \quad$ [Online]. Retrieved from: http://sumedangtandang.com/direktori/detail/desa-citengah.htm.

[11] R. Ridwan and C. Surya, "Pemberdayaan Masyarakat Desa Dalam Mengembangkan Ekonomi Kreatif di Desa Citengah Kabupaten Sumedang," Jurnal Riset Akuntansi Kontemporer, vol. 10, no. 1, pp. 2833.

[12] J. Fletcher, A. Fyall, D. Gilbert, and S. Wanhill, Tourism: Principles and practice. UK: Pearson UK, 2017.

[13] N.N.S. Astuti, Persepsi Wisatawan Mancanegara Terhadap Produk Pariwisata Bali. Bali: Pascasarjana Universitas Udayana, 2008.

[14] N. Febrina and W. Waryono, "Persepsi Wisatawan Tentang Daya Tarik Wisata Pemandian Tirta Alami Kabupaten Padang Pariaman," E-Journal Home Economic and Tourism, vol. 9, no. 2, 2015.

[15] I.B.D. Setiawan, Identifikasi Potensi Wisata Beserta 4A (Attraction, Amenity, Accessibility, Ancilliary) di Dusun Sumber Wangi Desa Pemuteran Kecamatan Gerokgak Kabupaten Buleleng Bali. Denpasar: Universitas Udayana Denpasar, 2015.

[16] N. Scheper-Hughes, Death Without Weeping: The Violence of Everyday Life in Brazil. Berkeley and Los Angeles: University of California Press, 1992.

[17] I.W. Ardika, Pariwisata dan Pelestarian Warisan Budaya. Denpasar: Program Studi Magister Kajian Pariwisata Universitas Udayana, 2001.

[18] O. Yoeti, Perencanaan dan Pengembangan Pariwisata. Jakarta: Pradaya Paramita, 2010

[19] L.J. Moleong, Metodologi Penelitian Kualitatif. Bandung: PT. Remaja Rosdakarya, 1988

[20] S. Haryono, "Penerapan Management Seni Pertunjukan pada Teater Koma," Harmonia, vol. VI, no. 3, 2005.

[21] H.H. Bisri, "Pengelolan Organisasi Seni Pertunjukan," Harmon. - J. Arts Res. Educ., vol. 1, no. 1, 2000.

[22] R. Soedarsono, Seni Pertunjukan Indonesia dan Pariwisata. Bandung: MPSI dan ARTI, 1999.

[23] I.K. Suwena and I.G.N. Widyatmaja, Pengetahuan dasar ilmu pariwisata Denpasar: Pustaka Larasan, 2017.

[24] I.G. Nurjaya, L.A. Tirtayani and I.K.R. Suwena, "Pemberdayaan Masyarakat Dalam Pengembangan Ekonomi Kreatif Berbasis Tri Hita Karana Di Desa Binaan Abang Batu Dinding Kecamatan Kintaman Kabupaten Bangli," International Journal of Community Service Learning, vol. 1, no. 1, pp. 17-25, 2017.

[25] Y. Sukmayadi and J. Masunah, "Organizing Bandung Isola Performing Arts Festival (BIPAF) As A Market of Innovative Performing Arts in Indonesia," Harmonia, vol. 20, no. 1, pp. 47-57, 2020. 